\title{
TRES VERSIONES DE LA ORFANDAD EN LA POESÍA DE CÉSAR VALLEJO
}

\author{
Three versions of orphanhood in César Vallejo's poetry
}

\author{
Irma Aniela Rodríguez Zapatal
}

\begin{abstract}
RESUMEN
En la vasta obra poética de César Vallejo, es posible identificar la ausencia y la nostalgia del tiempo pasado como registros temáticos presentes con cierta frecuencia. El presente artículo estudia el concepto de orfandad a través de tres variaciones del desamparo en la poesía de Vallejo. Para ello, se examinan aquí elementos tales como el espacio habitado, la figura de la madre y los paraísos perdidos, con la finalidad de indagar y contrastar las diferentes manifestaciones de la orfandad en el universo vallejiano.
\end{abstract}

Palabras clave: orfandad, ausencia, César Vallejo, poesía, paraísos perdidos, espacio habitado.

\begin{abstract}
In the vast poetic work of César Vallejo it's possible to identify then absence and nostalgia of past time as thematic records with some frequency. This article studies the concept of orphanhood through three variations of the helplessness presented in Vallejo's poetry. To do this we examine here events such as the inhibited space, the mother's figure, and the lost paradises in order to investigate and contrast the many manifestations of orphanhood in Vallejo's universe
\end{abstract}

Key Words: orphanhood, absence, César Vallejo, poetry, lost paradises, inhabited space.

\section{Hacia una hermenéutica vallejiana}

La obra poética de César Vallejo abarca tres momentos fundamentales que coinciden, en gran parte, con tres etapas cruciales de su vida. La etapa de Los Heraldos Negros encierra la vida rural en la provincia de Santiago de Chuco, aderezada con la valoración de la estética modernista y el surgimiento de una voz poética particular que emerge con fuerza. Posteriormente, se presenta Trilce, libro escrito durante el encarcelamiento del poeta, y donde se concretan las bases de loque se denominaría como la escritura de vanguardia: una experimentación desde lo lingüístico hasta la estructural, que se afianzó a través de la creación de neologismos, la transgresión de las formas

\footnotetext{
${ }^{1}$ Universidad Iberoamericana. Tesista. Campus Ciudad de México. México.

Correo electrónico: insomniaconvulsa@gmail.com

Recepción: 22-11-2017. Aceptación: 10-03-2018.
} 
poéticas y un sinfín de imágenes oscuras, que hasta la fecha la crítica ha tratado de desenmascarar. Por último, los Poemas Humanos presentan un universo cercano a las preocupaciones del hombre.

Hans-Georg Gadamer explica que la tarea hermenéutica de la poesía no puede permitirse quedar en el plano de lo descriptivo; por el contrario: debe explicar qué es lo que hace del poema un poema (2011, p. 100). Asegura que es posible pensar el arte sin el concepto de mímesis, no así el lenguaje (Gadamer, 2011, p. 101), y reconoce la existencia de varios planos que facilitan la comprensión de la poesía. El primero, el del lenguaje, en el que la polivalencia de las palabras se fija en tanto se establece el sentido del discurso; la palabra representa una realidad lingüística en el poema y por ello, supone que cada una de las unidades sea precisa para el efecto que busca causar.

En segunda instancia se encuentra el plano de las informaciones particulares: toda información externa que permita al lector completar su experiencia hermenéutica. Así, a su entendimiento, no existe lector alguno que entienda sin particularidades, y esto fundamenta que la comprensión de un poema no sea la misma en un lector que en otro. Sin embargo, ni el falso ideal de la información nula ni la accesibilidad total a la información validan nuestra comprensión del poema. Según Gadamer, ninguna interpretación es definitiva: todas aspiran a ser meras aproximaciones.

Gaston Bachelard afirma en su Poética del espacio que:

(...) la hermenéutica debe determinar los centros de destino, despojando a la historia de su tejido temporal conjuntivo, sin acción sobre nuestro propio destino. Para el conocimiento de la intimidad es más urgente que la determinación de las fechas la localización de nuestra intimidad en los espacios (2000, p. 32).

En este sentido, la hermenéutica surge como una herramienta que posibilita el encuentro de las particularidades en la poesía de Vallejo. Por su parte, Julio Ortega reconoce la existencia de una hermenéutica vallejiana que se caracteriza de esta manera:

La hermenéutica vallejiana probablemente no tiene fin, por su condición polisémica; aunque tampoco es sensato creer que la interpretación libre es la mejor, ya que este relativismo terminaría siendo acrítico (...) estos poemas propician un debate diverso, no pocas veces iluminador (Ortega, 1989, p. 620). 
La apuesta por un acercamiento a la interpretación en Vallejo es, sin duda alguna, arriesgada. Y sin embargo, el lector no puede abandonar el reto que ella propone.

\subsection{La orfandad del hombre en el mundo}

Hablar de César Vallejo es, claro está, hablar de la angustia; una angustia que, no obstante, se desenvuelve tras el velo de la ternura: no es coincidencia aquella imagen del hombre descobijado, arrebatado del seno protector. La obra del peruano se circunscribe en el registro de lo doloroso en sus distintas vertientes, pero sobre todo, nos habla de la punción del infante que mira el pasado con nostalgia. El pasado se ha ido, pero sigue siendo aquel fantasma que acecha al poeta; es la presencia de una ausencia. Por otra parte, traer el sufrimiento a la ecuación representa también poner en la mesa el universo del recuerdo. En la lírica vallejiana, conviven imágenes en las que pareciera brotar un lenguaje de la memoria: desde las imágenes de la patria perdida, hasta la casa de la infancia y los retratos paternos, existen un sinnúmero de referencias en las que el yo poético refiere a su pasado. Este pasado es a menudo traído al poema a la luz de un sentimiento de indefensión; por tanto, en el presente artículo, se ha decidido hablar sobre la orfandad en lapoesía de César Vallejo.

Dado que el término orfandad contempla varias acepciones, lo más conveniente es revisar las posibles definiciones del término. Para el Diccionario de la Real Academia Española, un huérfano es:

1. adj. Dicho de una persona menor de edad: A quien se le han muerto el padre y la madre o uno de los dos. U. t. c. s.

2. adj. poét. Dicho de una persona: A quien se le han muerto los hijos.

3. adj. Falto de algo, y especialmente de amparo. En aquella ocasión quedó huérfana la ciudad (RAE).

Aun y cuando la primera definición otorgada por la Real Academia Española hace énfasis en el panorama desolador, la poesía de Vallejo refleja la orfandad como un acontecimiento que no se circunscribe tan solo a la minoría de edad: la orfandad, según lo demuestra Vallejo en su poesía, no es una cuestión de edad, sino una condición crónica que el afectado carga hasta el fin de sus días. No obstante, la última definición es la que interesa en tanto que resulta más adecuada para el 
desarrollo de este trabajo. Así, el huérfano que presenta Vallejo a través de su poesía no solo es un ser despojado de sus padres, sino de todo lo que lo mantiene seguro. Por ende, se entenderá la orfandad como una condición que evidencia la carencia de amparo para el hombre; desde esta óptica, se analizarán tres distintas manifestaciones de la orfandad a través de tres textos representativos de la poesía de Vallejo.

La noción de orfandad es una constante alrededor de la obra vallejiana. El transitar desde Poemas Humanos hasta España, aparta de mí este cáliz expone la evolución de una voz poética con pocas certezas en el mundo, y que ha quedado desvalida; así queda manifiesto ya en "Espergesia", que cita "Yo nací un día que Dios estuvo enfermo, triste" (Vallejo, 1989, p. 114). La anagnórisis del yo poético se devela a raíz de ciertos elementos emparentados con la ausencia: por un lado, la importancia de las figuras paterna y materna, y por el otro, la dicotomía entre la partida y el regreso.

El primer poema fundamenta al espacio habitado como una zona de seguridad para el yo poético; en el segundo, la figura de la madre amante emerge para justificar su lugar en la memoria del poeta; y el tercero versa sobre la patria y su relación con la figura materna. El propósito es trazar una línea que permita dar cuenta de la orfandad del hombre en el mundo en el universo vallejiano, y plantear cómo se representa a lo largo de su poesía.

\subsection{Lo siniestro y lo ominoso}

Sigmund Freud desarrolló entre sus múltiples teorías el concepto de lo siniestro o unheimleich, que describe el sentimiento de extrañamiento y angustia ante lo novedoso. A través de ejemplos señalados en distintos textos narrativos, así como su propia experiencia en el campo del psicoanálisis, Freud realiza una radiografía de lo siniestro desde sus orígenes. El estudio, que primero comienza como un análisis lingüístico sobre la evolución de los vocablos heimlichunheimlich, termina teorizando acerca de la transición de lo familiar hacia lo siniestro. Para Freud, lo unheimlich se opone a heimlich, heimsch y vertraut. Los tres vocablos alemanes se adscribenal campo de lo íntimo, lo doméstico, lo familiar. Lo unheimlich se contrapone a todo esto: representa lo ominoso, lo secreto, lo oculto (Lo siniestro).

La angustia, continúa Freud, se origina por un recuerdo reprimido que vuelve; a partir de ello, lo familiar se torna angustioso, y por ende, se vuelve ominoso. Esta transición de lo familiar 
a lo siniestro no es causada porque el recuerdo sea angustioso: la sensación de traer de vuelta lo reprimido ocasiona una sensación indeseable en quien la experimenta. Lo unheimlich, por tanto, aparece íntimamente ligado al extrañamiento (Lo siniestro).

Hablar de lo siniestro es fundamental en la poesía de César Vallejo: primero, porque gran parte de su obra permanece en el registro de la angustia; y segundo, porque el alejamiento del hogar y la pérdida de los paraísos de la infancia son líneas temáticas constantes dentro de su producción. Vale la pena examinar que ya desde Los Heraldos Negros, Vallejo escribía desde la zozobra del unheimlich para decir: "Yo nací un día / que Dios estuvo enfermo, / grave" (Vallejo 1989, p. 114). A partir de esto, la voz poética en Vallejo es sincera y centellante: reconstruye, reconfigura, instala la memoria en la palabra.

Según E. Jenstch, continúa Freud, lo siniestro se presenta cuando el hombre se siente desorientado en el mundo; así, lo novedoso, lo que no resulta familiar en el sentido más amplio de la palabra, deviene en la angustia. En cuanto uno se encuentre más orientado, es menos posible que las cosas ante él se revelen como siniestras: lo nuevo, lo que la conciencia no ha aprehendido del todo, resulta siempre desconcertante, y plantea la sensación de estar perdido en el mundo (Lo siniestro).

La angustia del unheimlich es, en Vallejo, necesaria para expresar la orfandad del hombre en el mundo. Así lo deja ver en múltiples ocasiones, sea tal: "Algo te identifica con el que se aleja de ti, y es la facultad común de volver: de ahí tu más grande pesadumbre” (Vallejo, 1989, p. 434). Eugenio Chang-Rodríguez comenta que la comprensión de este constante estado de angustia en Vallejo “(...) ayuda a explicar las desviaciones semánticas de su volitivo desquiciamiento lingüístico" (1977, p. 49). Puede hablarse de que a raíz de la pérdida de los espacios íntimos, en la poesía de Vallejo se desencadena una voz poética que busca recuperar esos espacios perdidos y habitarlos en función del recuerdo. Si lo logra es a través de la experimentación sintáctica y el bombardeo de imágenes que, sin necesidad de un lenguaje adornado y rimbombante, crean la atmósfera de lo unheimlich y evidencian la nostalgia por el tiempo perdido. 


\section{Tres figuraciones de la orfandad en la poesía de César Vallejo}

\subsection{El hogar, un paraíso perdido}

En Poética del espacio, Gaston Bachelard insiste que “(...) la casa es nuestro rincón del mundo. Es -se ha dicho con frecuencia- nuestro primer universo. Es realmente un cosmos. Un cosmos en toda la acepción del término. Vista íntimamente, la vivienda más humilde ¿no es la más bella?” (2000, p. 28). Como se afirma en estas líneas, el universo del hogar es también el lugar del nacimiento. Representa nuestra esfera inmediata y encierra dentro de sí el espacio donde emergen nuestros recuerdos. El espacio habitado, como asegura Bachelard en sus planteamientos, es aquel lugar al que nombramos casa. ¿No es entonces el hogar una extensión de nuestra memoria?

En la poesía de César Vallejo, se incorporan las nociones de «lo habitado » para invocar a los fantasmas del recuerdo; sus imágenes trascienden con base en la edificación de un particular universo, el del recuerdo y la memoria del tiempo perdido. En Lógica del sentido, Gilles Deleuze construye, a través de las nociones de memoria y olvido, un concepto por demás interesante: el de fantasma. El planteamiento de Deleuze propone: “(...) el fantasma tiene la propiedad de poner en contacto lo exterior y lo interior, y reunirlos en un solo lado. Por esa razón es el lugar del eterno retorno" (Deleuze, 2010, p. 158). La noción de fantasma, según Deleuze, se origina por un suceso real capaz de referir a un acontecimiento virtual existente en el pasado; es decir, el fantasma funciona como un puente mnemónico entre la realidad pasada y la impresión que el hombre posee de ella.

Las alusiones al hogar perdido -el espacio habitado, la lejanía de la patria, los padres ausentes- son cuantiosas en la obra poética de César Vallejo. Ya desde Canciones de hogar, el apartado final de Los Heraldos Negros, se percibe un bosquejo del paraíso perdido: elalejamiento de la casa paterna, tema latente dentro del universo vallejiano. A través de una primera lectura es posible descubrir la zozobra de la voz poética al referir a la ausencia como un motivo fundamental. Se trata tan solo de la premonición del desencuentro, y la reafirmación de la voz poética de que cualquier tiempo pasado fue mejor.

"No vive ya nadie" es el ejemplo más claro de este planteamiento, pues en él se propone toda una concepción sobre la casa como una zona de encuentro entre el presente y la memoria de la ausencia. Se trata de un texto correspondiente a la sección Poemas en Prosa, incluida en el corpus 
de Poemas Humanos y que forma parte de un grupo de textos escritos en forma de prosa poética; por tanto, no contiene elementos de versificación o rima que nos hagan pensar en la estructura tradicional lírica. El título, "No vive ya nadie”, responde al primer enunciado del texto. La apertura del poema anuncia una entrada peculiar:

— No vive ya nadie en la casa — me dices—; todos se han ido. La sala, el dormitorio, el patio, yacen despoblados. Nadie ya queda, pues que todos han partido (Vallejo, 1989, p. $323)$.

La primera palabra es un adverbio de negación. El enunciatario simula entablar un diálogo con otro sujeto, enunciado en segunda persona. Su identidad no es revelada; sin embargo, el poema deja ver al otro que entra en escena. La estructura es interesante: vale la pena preguntarse por aquel juego enunciatario que Vallejo lanza a través de aquella segunda persona: ¿es a nosotros a quienes habla, o acaso alguien más se esconde bajo el disfraz del lector? Así se justifica desde el inicio un juego de oposiciones que se presentará en las líneas subsecuentes.

Desde este primer momento ya queda manifiesta la ausencia de los otros: aquellos de los que no se dice el nombre, pero que continúan impregnando la atmósfera con su paso. La colectividad, implícita en el pronombre 'todos', justifica el llamamiento tanto a una minoría como a la humanidad entera. La elección de este pronombre permite el poema; así, toda particularidad queda supeditada a la interpretación del lector, y a su propia noción de aquellos que ya no están.

Todos se han ido, asegura este primer enunciatario, pero, ¿quiénes son los que parten y quiénes permanecen? En un segundo momento de la lectura, la pérdida parece irreparable, dado que el espacio ha dejado de ser habitado. Sin la casa, continúa Bachelard, el hombre sería un ser disperso, arrojado al mundo sin la bondad de esa cuna que representa el hogar. La casa es un paraíso material: nutre al hombre y lo llena de todos los bienes esenciales (2000, p. 30). Es, en el fondo, el punto de origen del hombre:

Y yo te digo: Cuando alguien se va, alguien queda. El punto por donde pasó un hombre, ya no está solo. Únicamente está solo, de soledad humana, el lugar por donde ningún hombre ha pasado. Las casas nuevas están más muertas que las viejas, porque sus muros son de piedra o de acero, pero no de hombres (Vallejo, 1989, p. 323).

Posteriormente, la voz poética responde al planteamiento lanzado en el primer párrafo y explícitamente se enuncia como un 'yo'. Esto permite hacer énfasis en la estructura del diálogo. Al 
existir un 'yo' y un 'tú', el diálogo se vuelve más íntimo, pues se redondea en la posibilidad de un 'nosotros'. Ahora bien: la dicotomía entre 'cuando alguien se va, alguien queda' sugiere un nuevo elemento en juego: la presencia de lo ausente, que ya compromete una paradójica forma de ver el mundo. El recuerdo se actualiza conforme es traído de vuelta al presente; la memoria no registra la duración tal cual acontece, sino que solo hace posible retomarla en un sentido abstracto. Así se genera esta noción de lo presente y lo ausente.

Siguiendo esta misma línea, la voz lírica equipara la construcción de una casa con el nacimiento de un hombre. La construcción 'viene al mundo' es un eufemismo del parto: venir al mundo es también habitarlo, hacerlo propio, llamarlo a existir con nosotros. No sorprende de la misma forma que se dedique a compararla con una tumba; la casa, para la voz poética, encierra el ciclo vital del ser humano.

Una casa viene al mundo, no cuando la acaban de edificar, sino cuando empiezan a habitarla. Una casa vive únicamente de hombres, como una tumba. De aquí esa irresistible semejanza que hay entre una casa y una tumba. Únicamente que la casa se nutre de la vida del hombre, mientras que la tumba se nutre de la muerte del hombre. Por eso, la primera está de pie, mientras que la segunda está tendida (Vallejo, 1989, p. 323).

La contraposición casa-tumba hace pensar también en un contraste de elementos: la tierra versus el cielo, lo animado versus lo inanimado, la vida versus la muerte. No obstante, esto repara en una visión integradora, en la que la vida y la muerte conviven en un mismo plano.

Todos han partido de la casa, en realidad, pero todos se han quedado en verdad. Y no es el recuerdo de ellos lo que queda, sino ellos mismos. Y no es tampoco que ellos queden en la casa, sino que continúan por la casa. Las funciones y los actos se van de la casa en tren o en avión o a caballo, a pie o arrastrándose (Vallejo, 1989, p. 323).

De esta manera, la voz poética asume la casa como un espacio vacío. Resulta interesante reparar en la construcción sintáctica de este fragmento. Primero que nada, el yo poético afirma que 'no es el recuerdo de ellos lo que queda, sino ellos mismos', con lo cual, por un lado, niega la ausencia de los que habitan el espacio, y por otro, supone que lo que permanece es de fuerza más poderosa que la del recuerdo.

Ahora bien: la voz poética corrige el verbo 'quedar' por 'continuar', cuando afirma que 'no que es que ellos queden en la casa, sino que continúan por la casa”. El primero anuncia una 
impresión definitiva: lo que se queda se imprime una vez y para siempre. Del otro lado, lo que continúa pareciera advertir sobre una presencia que no termina de irse y que sigue pasando en activo. En Vallejo los muertos, los ausentes, nunca terminan de morir del todo: la voz poética continúa llamándolos en aquel extraño limbo, por donde transitan en forma de recuerdos.

El juego de contrarios permite pensar en dos esferas semánticas en contraposición: la vida y la muerte. A través de la antítesis entre irse-quedarse, continuar-partir, casa-tumba, se representa el conflicto central del poema.

La casa de la que Vallejo habla se cimienta en las ruinas de un paraíso perdido que ya se ha dejado atrás; prueba de ello es el hecho de que 'todos se han ido', dejando al yo lírico en una orfandad de doble nivel: lo espacial y lo existencial. La memoria, el tiempo, el espacio: tres elementos fundamentales para entender el juego dialógico de este poema, y sin lugar a dudas, para comprender a mayor profundidad el universo poético vallejiano.

Para Guillermo Sucre, "No vive ya nadie" es un texto complejo, pues encierra el poderoso mecanismo del recuerdo: "Este mundo permanece, pues, no por la simple virtud evocadora de la memoria. Es un presente vivo y victorioso contra el que no pueden ni el tiempo ni la muerte" (1974, p. 421). El espacio tiende un puente entre lo presente y lo ausente; llama al recuerdo e invoca a lo que se ha ido, pero que permanece a través de la memoria. Está pasando y, sin embargo, nunca termina de pasar: en la casa se representa la fusión de horizontes entre el mundo de los vivos y el de los muertos. Quizás ese punto de encuentro es el que Vallejo ha querido retratar, aquella zona de la memoria de lo fugitivo.

La imagen de la casa en César Vallejo es, según Natalia Gómez, una confrontación de la visión occidental del tiempo y el espacio contra la concepción inca sobre la vida y la muerte. La tradición inca, continúa, concebía que después de la muerte, el cuerpo volvía al mundo para habitarlo (2004, p. 8). De esta forma, el diálogo entre los dos sujetos del poema también representa una integración de dos perspectivas, síntoma recurrente dentro de la poesía de Vallejo.

El hogar de la infancia es la invocación de un paraíso perdido. La casa es protagonista del poema: se habla de ella, se pone en juego, se habita. La fugacidad de la vida se evidencia en la contraposición de los elementos materiales (los muros, el suelo, el techo) con los propiamente humanos. Al parecer, en Vallejo la imagen de la casa carga cuestiones de mayor peso, como el ciclo de la vida y la muerte, la dicotomía entre ánima y cuerpo y la permanencia del recuerdo a 
través del tiempo. Esta enumeración de recursos nos propone un contraste entre lo permanente, relativo a la construcción y los cimientos de la casa, y lo fugitivo, que alude al carácter transitorio del hombre en el mundo.

\subsection{La madre como figura de protección}

En una carta a su hermano Manuel, fechada en Lima en octubre de 1918, César Vallejo escribe:

En este mundo no me queda nada ya. Apenas el bien de la vida de nuestro papacito. Y el día que esto haya terminado, me habré muerto yo también para la vida y el porvenir, y mi camino se irá cuesta abajo. Estoy desquiciado y sin saber qué hacer, ni para qué vivir. Así paso mis días huérfanos lejos de todo y loco de dolor (Rivera Feijóo, 1984, p. 41).

La ausencia de los padres es un tópico fundamental en la poesía de César Vallejo. A lo largo de su obra, son recurrentes las imágenes que remiten al lecho parental o a la casa paterna.El alejamiento de la vida en Perú y la muerte del padre y la madre son acontecimientos que acentúan el sentimiento de orfandad en el mundo; para Vallejo, la poesía es uno de los refugios donde le es posible traer de vuelta el pasado para reconstruirlo.

En Arquetipos e inconsciente colectivo, Carl Jung dedica un apartado a teorizar sobre la figura de la madre; por medio de un sinnúmero de referencias, hace una radiografía con la cual da cuenta del peso de la madre en distintas mitologías. Con ello, expone la figura de la diosa madre, íntimamente ligada al equilibrio universal y que busca la estabilidad de los hombres. Refiere que el cristianismo ha utilizado este recurso para la creación de imágenes como la Virgen María, que replantea lo que las mitologías ya habían concretado para trasladarlo a una estampa más terrenal.

Jung distingue dos formas de representación de la figura materna: la madre amante y la madre terrible. Jung afirma que la madre actúa como un símbolo de protección, y al mismo tiempo representa una serie de características que le confieren su cualidad de arquetipo: “(...) lo 'materno', la autoridad mágica de lo femenino, la sabiduría y la altura espiritual que está más allá del entendimiento; lo bondadoso, protector, sustentador, dispensador de crecimiento, fertilidad y alimento; los sitios de la transformación mágica, el renacimiento" (1970, p. 75). Así pues, lo que Vallejo propone a lo largo de su producción es lo considerado dentro de la teoría jungiana como 
una madre amante, que va adquiriendo distintos matices, pero que permanece como una figura de protección ante la que la voz poética acude recurrentemente.

Así se manifiesta en el poema "El buen sentido", que según Mariano Ibérico, es el último que Vallejo dedica explícitamente a su madre. Este texto está contenido dentro del apartado de Poemas en prosa, y propone una introspección del yo poético con la figura materna ausente:

Hay, madre, un sitio en el mundo, que se llama París. Un sitio muy grande y lejano y otra vez grande.

Mi madre me ajusta el cuello del abrigo, no porque empieza a nevar, sino para que empiece a nevar (Vallejo, 1989, p. 309).

Primero que nada, habrá que notar el extrañamiento con el que la voz poética habla de París, refiriéndose como un sitio en el mundo, como si se tratase de un lugar cualquiera. Posteriormente, lo identifica como grande y lejano, con lo que en primer lugar notamos la referencia de un mundo extraño para el sujeto lírico, y segundo, la necesidad de abrigo que se manifiesta ante la figura de la madre. Esta proposición pone de manifiesto la indefensión del yo poético ante el gran París, que se erige ante él devorándolo. El primer párrafo ya subraya un lenguaje de la inocencia; basta pensar en la construcción sintáctica para advertirlo: "Un sitio muy grande y lejano y otra vez grande" (Vallejo, 1989, p. 309) se presenta ante el lector a partir de un habla infantil, donde se justifican las sensaciones hiperbolizadas.

Esta indefensión del yo poético ante la figura materna continúa en el segundo párrafo, donde aparece el gesto compasivo de la madre. Habrá que apuntalar los tiempos verbales y la construcción de la oración, toda vez que las acciones ocurren aparentemente a la inversa: la madre acomoda el cuello del abrigo al yo poético no como una consecuencia, sino como la invocación a la nevada. Construcciones como esta se encuentran a lo largo de la poesía de Vallejo.

"El buen sentido" hace una reconstrucción del recuerdo: el yo poético trae a la figura materna, la invoca nombrándola una y otra vez. Configura la estampa del pasado y, sin embargo, también evidencia el choque de dos tiempos: el pasado que se ha ido para no volver, y el presente que amenaza constantemente.

Lo siguiente permite dar una imagen más clara de la angustia del yo poético ante la ausencia de la madre; nótese: 
La mujer de mi padre está enamorada de mí, viniendo y avanzando de espaldas a mi nacimiento y de pecho a mi muerte. Que soy dos veces suyo: por el adiós y por el regreso. La cierro, al retornar. Por eso me dieran tanto sus ojos, justa de mí, in fraganti de mí, aconteciéndose por obras terminadas, por pactos consumados (Vallejo, 1989, p. 309).

Atribuimos que al cambiar el vocablo 'madre' por 'la mujer de mi padre', el yo poético permite también convertirla en un sujeto erotizado. Así, la figura de la madre nutricia, como asegura Dreyfus, abandona el papel de hijo para competir, virtualmente, con la imagen de su padre: seduce a la progenitora a través de su adultez, y por tanto, le recuerda su virilidad. Esto, continúa, se origina en parte gracias a la pulsión vital del eros versus el tánatos: la madre erotizada en oposición a la madre muerta (Dreyfus, 1998).

Hay que recordar la nota que Américo Ferrari hace a este poema en su estudio filológico. En la versión manuscrita de "El buen sentido" existe un fragmento desaparecido de la versión definitiva. En él, se lee:

¿Qué hay [,pues,] en mí, que falta en mi padre y, desde mi vuelta al hogar [pone tan pensativa] activa de continuo infortunio a mi madre? Ya mi padre pierde su autoridad y el hogar oscilará, en torno mío, con manga, filete, galón y solapas (Vallejo, 1989, p. 310).

Dicho pasaje contribuye a conformar lo que anteriormente se propuso: hay en este poema un dejo de erotismo en la relación madre-hijo. La pérdida de autoridad del padre, aunado con lo que el hijo tiene y que el padre carece pareciera tener que ver con un acercamiento más íntimo a la madre. Recordemos que el vínculo del hijo con su progenitora es indubitable:

El fenómeno, bien observado, permite una perspectiva análoga a la por él ofrecida: espacio de infancia es espacio materno, o sea, "amparo", "nutrición"; como espacio actual es de soledad, abandono, orfandad. El regreso a lo primigenio, el movimiento de retorno, es búsqueda del sostenimiento perdido (...). Por ello, es que esos lugares de la niñez se transforman en objeto intencional, conocido, seguro y siempre actuante como punto concreto de necesaria atracción (Coddou Pebbles, 2001, p. 36).

Este espacio de la infancia representa, en "El buen sentido", el lugar habitado por la madre. En ella, el yo poético encuentra la posibilidad del consuelo y del amparo. Es así que, como dice Coddou Pebbles, el sujeto que participa en este poema retorna a su hogar y origen: la madre. 
Mi madre acuerda carta de principio colorante a mis relatos de regreso. Ante mi vida de regreso, recordando que viajé durante dos corazones por su vientre, se ruboriza y se queda mortalmente lívida, cuando digo, en el tratado del alma: Aquella noche fui dichoso. Pero, más se pone triste; más se pusiera triste.

—Hijo, ¡cómo estás viejo! (Vallejo, 1989, p. 310).

Es interesante notar cómo la madre se ruboriza primero y queda lívida después: un juego opositorio en el que conviene detenernos un momento. El rubor es un signo que, a través del tiempo, ha sido considerado como señal de buena salud; por otro lado, la lividez denota lo opuesto: la enfermedad y la muerte. Ya en Trilce, Vallejo había llamado a su madre 'muerta inmortal'. No dudamos que este juego de oposiciones aluda a ello.

Finalmente, la madre nota que el paso del tiempo también cobra la vida de su hijo. Se entristece, pues, ante la advertencia de una vida perecedera. El extrañamiento de la madre al hijo se produce al momento en el que ella advierte la madurez en su hijo. Este pasaje sugiere un encuentro de lo pasado con lo presente: es por ello que la madre, al contemplar a su hijo envejecido, toma conciencia de la fugacidad de la vida:

(...) porque me halla envejecido, en la hoja de espada, en la desembocadura de mi rostro. Llora de mí, se entristece de mí. ¿Qué falta hará mi mocedad, si siempre seré su hijo? ¿Por qué las madres se duelen de hallar envejecidos a sus hijos, si jamás la edad de ellos alcanzará a la de ellas? ¿Y por qué, si los hijos, cuanto más se acaban, más se aproximan a los padres? (Vallejo, 1989, p. 310).

Las preguntas que lanza el yo poético corresponden a un recurso socorrido en sendas ocasiones por el autor: a través de ellas, busca increpar directamente al lector; lo llama a habitar el poema con él. Estas tres preguntas, a final de cuentas, son parte del dolor que embarga al sujeto poético. Lo que buscan no es una respuesta (pues claramente carecen de ella), sino la atención de un interlocutor dispuesto a escuchar sus lamentos.

Universalizar a la imagen de la madre es también parte de la inclusión al lector en el poema. Así, ya no solo se trata de la madre del yo poético, sino de todas las madres del mundo, incluyendo la nuestra. El llamamiento nos involucra, nos hace parte del poema. El poema finaliza con la misma sentencia con la que daba apertura: 
- Hay, madre, en el mundo un sitio que se llama París. Un sitio muy grande y muy lejano y otra vez grande.

La mujer de mi padre, al oírme, almuerza y sus ojos mortales descienden suavemente por mis brazos (Vallejo, 1989, p. 310).

Así, el yo poético nos revela una verdad desgarradora: la madre, que ha protegido al hijoy lo ha acunado en su retorno, es en realidad un recuerdo reconstruido por el autor. Los ojos mortales de la madre nos advierten sobre el fantasma del recuerdo que ha llegado a habitar el poema.

Con el cierre, la idea de lo ominoso se hace presente en el texto; recordemos a Freud que proponía el término unheimlich para referirse a la sensación producida por algo novedoso, que se opone a lo familiar (Lo siniestro). Los siniestros ojos de la madre muerta se contraponen a la mirada compasiva de la madre amante que estuvo presente en todo el poema. Lo familiar se convierte en siniestro con la transposición de un elemento. La madre compasiva y generosa se convierte súbitamente en extraña, al mismo tiempo que se revelan ante nosotros sus ojos mortales.

Vallejo no volvería a mencionar a su madre, salvo la alusión hecha en "La violencia de las horas", donde escribe: "murió en mi revólver mi madre (...)” (Vallejo, 1989, p. 308). Sin embargo, el vínculo que guarda con ella queda plausible a lo largo de su poesía; "El buen sentido" representa el último acecho de la figura materna que fundamenta el desgarramiento lírico en Vallejo, y pone en entredicho la orfandad del yo poético en el universo.

\subsection{La caída de la Madre Patria}

En 1937, estalló la Guerra Civil española, conflicto que sacudiría y desangraría a España por casi tres años, y dejaría a su paso unas cuantas décadas de severas repercusiones sociales, económicas y culturales. En la Guerra Civil, estaban en juego importantes consideraciones no solo para España, sino para el mundo entero: se buscaba frenar con el fascismo que acechaba a Occidente, principalmente a través de Italia y Alemania. Un buen número de personas se unieron a las Brigadas Internacionales para sumarse al movimiento republicano. Tal fue el caso de César Vallejo. Militante marxista y activista comprometido, el poeta escribe España, aparta de mí este cáliz en respuesta a los conflictos que tenían lugar por aquella época. 
El poemario fue incluido como parte de los Poemas Humanos, aun y cuando se trata de composiciones temáticamente independientes a las demás. En el post scriptum a la primera edición de España..., Juan Larrea escribe:

No hace aún dos años que murió César Vallejo (...) Como él, España ha muerto (...) Ha muerto la MADRE. Ha muerto sola, después de apurar su cáliz de amargura, sin más asistencia que el desconsuelo de los pueblos que en ella tenían puestos los ojos (1961, p. 18).

Larrea apuntaba a la desazón sufrida por todos aquellos que compartían en España no solo un territorio, sino el cobijo de una madre.

La primera versión de España, aparta de mí este cáliz, fue impresa y distribuida por los soldados republicanos del Ejército del Este, sobre papel que ellos mismos habían fabricado.

A lo largo del poemario, Vallejo toma la figura de la Madre Patria y la personifica; así, a lo largo del apartado se puede ver a una madre dolida y dolorosa, sobre la cual sus hijos, los combatientes, terminan por dejarla malherida. La figura de la madre nutricia aparece de nuevo para recordar al lector cuán relevante es España como símbolo del origen. Ejemplo fundamental de ello es el poema titulado "España, aparta de mí este cáliz", que da nombre al apartado. Dice André Coyné:

Desde que dejó a su madre, y su madre a su vez lo dejó, Vallejo ha invocado el nombre y la imagen querida hasta llegar (... 'HIJO ETERNO’ de una 'madre unánime', la cual ahora identifica con la patria de Cervantes, de Quevedo, de Teresa (1999, p. 225).

Esta idea permite que Vallejo encuentre en España una nueva madre protectora, pero también agonizante, y a quien escribe desde el desgarramiento y el dolor:

¡Niños del mundo, está

la madre España con su vientre a cuestas;

está nuestra madre con sus férulas,

está madre y maestra,

cruz y madera, porque os dio altura, 
vértigo y división y suma, niños;

está con ella, padres procesales! (Vallejo, 1989, p. 481).

Presuponiendo que el vientre es el símbolo corporal de la fecundidad y por tanto, de la maternidad, el vientre a cuestas alude al gran peso con el que la madre va cargando; un peso que parece soportar por el bienestar de sus hijos. Asimismo, es fundamental notar que lleva en el cuerpo algunas férulas, lo que nos habla de una madre herida en lo más profundo de su ser. Las fracturas de la Madre España son una metáfora que, aunque pareciera vaga, no termina de expresar el dolor de la voz poética ante la maternidad malherida.

“España, aparta de mí este cáliz” es más que un poema, un llamamiento a la acción. La voz poética busca que todos los niños, hijos de España, no tarden en auxiliarla. A través del recurso de la Madre Patria, la voz poética construye un retrato nítido de la madre protectora que, al mismo tiempo, está por caer.

En los siguientes versos, el yo poético pareciera advertir a los niños de España. Siguiendo con la línea del diálogo (un simulado interlocutor que a la vez, remite al lector):

Si cae -digo, es un decir-si cae

España, de la tierra para abajo,

niños ¡cómo vais a cesar de crecer!

¡cómo va a castigar el año al mes!

¡cómo van a quedarse en diez los dientes,

en palote el diptongo, la medalla en llanto! (Vallejo, 1989, p. 482).

A lo largo del poema, Vallejo procura la expresión "es un decir" cuando se refiere a la caída de España, con lo que otorga un grado hipotético a la situación. Con ello, el yo poético evidencia el miedo a que esto de verdad ocurra; por eso, se asegura de no dar nada por sentado. En los versos posteriores, se preocupa por inquirir a los niños sobre las consecuencias de la caída de España. De esta manera, y en una enumeración de imágenes oscuras, finalmente dota a España de las atribuciones de una madre: la posibilidad de ver crecer a sus hijos.

La caída de España es claramente simbólica; no obstante, no lo son los niños de los que habla el yo poético. Que la madre caiga significa, también, que la figura de protección será 
erradicada, con lo cual dejaría a los habitantes - esos niños del mundo de los que habla el poemaen una orfandad inefable:

¡Bajad el aliento, y si

el antebrazo baja,

si las férulas suenan, si es de noche,

si el cielo cabe en dos limbos terrestres,

si hay ruido en el sonido de las puertas,

si tardo,

si no veis a nadie, si os asustan

los lápices sin punta, si la madre

España cae — digo, es un decir-

salid, niños del mundo; id a buscarla!...(Vallejo, 1989, p. 482).

De nuevo, se hace referencia a las férulas, que probablemente sea una referencia de dos niveles: las de la Madre España, en el principio del poema, y las de los heridos por la guerra. El antebrazo que baja haría referencia a los caídos, pues representa una imagen representativa de la muerte en el combate.

La figura de la madre herida es un recurso de mucha valía dentro de España, aparta de mí este cáliz. En primer lugar, porque en ella está contenida el símbolo de una nación lastimada por el régimen. Asimismo, Vallejo también pareciera dibujar los contornos de la femineidad sometida, en este caso, analogándola al fascismo y las luchas por el poder en la primera mitad del siglo XX.

“España, aparta de mí este cáliz" es un poema escrito desde la esperanza. Es un llamado a la revolución, pero también es una búsqueda por el despertar de la conciencia. En un juego dialéctico en el que convive el poeta y las nuevas generaciones, la Madre Patria parece ser el elemento común de la lucha. Partiendo de ella, tal como plantea el poema, es posible unirse en una colectividad (la revolución) para salvar la figura materna que, aún malherida, sobrevive.

Para Vallejo, la Guerra Civil española representa un llamamiento necesario a la cohesión social, pero también un lamento por aquellos que han quedado arrojados al mundo. Este doble nivel 
del abandono pareciera estar presente a través de todo el libro, en el cual los cadáveres se apilan como troncos, pero la Madre España sobrevive. La orfandad del hombre adquiere una dimensión social en cuanto este es despojado de sus ideales.

Ya desde los Heraldos Negros, en la poesía César Vallejo se mostraba patente su interés por los temas sociales al retratar la vida de los obreros y mineros en el Perú de antaño. Sin embargo, en España se representa un vínculo territorial: la madre que España representa para los latinoamericanos es también la única figura materna que permanece accesible al poeta. Sin menguar el gran compromiso social que Vallejo sentía por la humanidad entera, en "España, aparta de mí este cáliz" se observa la imagen de la madre primigenia, a través de la cual el poeta encuentra un refugio. Huérfanos de padres y huérfanos de origen, los hijos de España son la imagen que Vallejo retrata constantemente a lo largo de su poesía: hombres despojados de su ascendencia y su lugar de origen. A ellos solo queda el consuelo de la lucha.

\section{Bibliografía}

Bachelard, Gaston. (2000). La poética del espacio. Buenos Aires: Fondo de Cultura Económica. Chang-Rodríguez, Eduardo. (1977). Sobre la angustia y las alteraciones. Revista de Crítica Literaria Latinoamericana, (5), 49-55.

Coddou Peebles, Marcelo. (2001). “El recuerdo en la poesía de César Vallejo”. En Wilfrido Kapsoli (Ed.), César Vallejo en la crítica internacional (pp. 27-53). Perú: Universidad Ricardo Palma.

Coyné, André. (1999). Medio siglo con Vallejo. Perú: Pontificia Universidad Católica del Perú.

Deleuze, Gilles. (2010). Del fantasma. Lógica del sentido (pp. 151-155). Santiago de Chile: Escuela de Filosofía Universidad ARCIS.

Dreyfus, Mariela. (1998). “Tres figuraciones de la 'madre’ en Vallejo”. Alma Mater, (15), 47-60.

Freud, Sigmund. (1919). Lo siniestro. Recuperado de https:/www.ucm.es/data/cont/docs/1192014-02-23-Freud.LoSiniestro.pdf. Consulta 20 de abril de 2016.

Gómez, Natalia. (2004). De la carne a la piedra: conceptualización arqueológica de la casa en la poesía de César Vallejo. Taller de letras, (34), 7-24. 
Ibérico, Mariano. (1974). El sentido del tiempo en la poesía de César Vallejo. En Julio Ortega (Ed.), César Vallejo. España: Taurus.

Jung, Carl. (1970). Arquetipos e inconsciente colectivo. España: Paidós.

Larrea, Juan. (1961). Post Scriptum. En Vallejo, César. España, Aparta de mí este cáliz, (pp. 1819). Lima: Perú Nuevo.

Ortega, Julio. (1989). La hermenéutica vallejiana y el hablar materno. En Vallejo, César. Obra poética (pp. 606-620). México: UNESCO.

Rivera Feijóo, Juan Francisco. (1984). César Vallejo: mito, religión y destino. Perú: Amaro Ediciones.

Sucre, Guillermo. (1974). La nostalgia de la inocencia. En Julio Ortega (Ed.), César Vallejo. Madrid: Taurus.

Vallejo, César. (1989). Obra poética. México: UNESCO.

\section{@ $\odot \otimes \odot$}

Esta obra está bajo una licencia de Creative Commons Reconocimiento-NoComercial-SinObraDerivada $\underline{4.0 \text { Internacional }}$ 